\title{
KEPRIBADIAN TOKOH JUN DALAM NOVEL TIGA CINTA, IBU KARYA GUS TF SAKAI (KAJIAN PSYCHO-SOCIALCRISIS ERIKSON)
}

\author{
Samsiarni \\ Program Studi Pendidikan Bahasa dan Sastra Indonesia \\ STKIP PGRI Sumatera Barat \\ Email : samsiarniyessi@yahoo.co.id \\ Submitted :10-05-2016, Reviewed:15-10-2016, Accepted:31-10-2016 \\ http://dx.doi.org/10.22202/JG.2016.v2i2.1205
}

\begin{abstract}
This study aims to look at the problem of identity is represented through Jun characters in the novel Tiga Cinta, Ibu works of Gus Tf Sakai using the theory of psycho-crisis Erikson. Jun figure is a representation of the Minangkabau people who experience confusion against social identity due to the clash between tradition and modernity. This research uses descriptive method with content analysis approach. The results showed that the novel Tiga Cinta, Ibu works of Gus Tf Sakai show problems of identity in the form of confusion of identity experienced, Jun as the Minangkabau people who have long lived outside the Minangkabau area. Minangkabau identity as people make should be in bonds that tradition forced him to not marry his bride for indigenous pedigree. This confusion makes Jun figures were in a dilemma to accept or reject the clash of tradition and modernity that happened. In the end he decided not to follow the rules of tradition. The choice made by leaders in Jun is a form of identity crisis experienced by the public in part today.
\end{abstract}

Keywords: identity, tradition, modernity, novel.

\section{Abstrak}

Penelitian ini bertujuan untuk melihat permasalahaan identitas yang terepresentasi melalui tokoh Jun dalam novel Tiga Cinta, Ibu karya Gus Tf Sakai dengan menggunakan teori psycho-crisis Erikson. Tokoh Jun merupakan representasi masyarakat Minangkabau yang mengalami kegamangan terhadap identitas sosialnya dikarenakan terjadinya benturan antara tradisi dan modernitas. Penelitian ini menggunakan metode deskriptif dengan pendekatan konten analisis. Hasil penelitian menunjukkan bahwa novel Tiga Cinta, Ibu karya Gus Tf Sakai memperlihatkan permasalahan identitas berupa kebingungan identitas (identity confusion) yang dialami tokoh Jun sebagai orang Minangkabau yang telah lama hidup di luar Minangkabau. Identitasnya sebagai orang Minangkabau membuatnya harus berada dalam ikatan tradisi tersebut yang memaksanya untuk tidak menikahi calon istrinya karena silsilah adat. Kebingungan ini membuat tokoh Jun berada dalam dilema untuk menerima atau menolak dalam perbenturan tradisi dan modernitas yang dialaminya. Pada akhirnya ia memutuskan tidak mengikuti aturan tradisi. Pilihan yang diambil oleh tokoh Jun adalah bentuk krisis identitas yang dialami oleh sebagaian masyarakat dewasa ini.

Kata kunci : identitas, tradisi, modernitas, novel.

\section{PENDAHULUAN}

Karya sastra, khususnya novel, diciptakan oleh pengarang dengan tujuan untuk dinikmati, dipahami, dan dimanfaatkan tanpa melupakan bahwa karya sastra sebenarnya merupakan 
pengungkapan masalah hidup, filsafat, dan ilmu jiwa (Hastuti, 2014). Salah satu teori yang bisa digunakan dalam menganalisis karya sastra dalam bentuk novel adalah psikoanalisis. Konsep ini pertama kali dikenalkan oleh Sigmund Freud. Teori psikoanalisis Freud (1856-1983) membedakan struktur kepribadian menjadi tiga komponen, yaitu ; id, ego, dan superego. Tiga komponen struktur inilah yang memiliki peranan penting dalam pembentukan keperibadian seorang manusia, seperti dalam tahap perkembangan kepribadian dan dinamika kepribadian.

Teori Freud, awalnya banyak dipandang hanya berhasil untuk mengungkapkan permasalahan genesis karya sastra, sehingga sering dikaitkan dengan penelitian proses kreatif. Hal ini disebabkan pada mulanya orang berpandangan bahwa psikologi lebih tepat diterapkan terhadap orang yang menghasilkan karya sastra sebagai salah bentuk resepsinya atas hasrat akan sesuatu. Freud menjelaskan bahwa orang bisa menggunakan berbagai media untuk penyaluran hasratnya terhadap sesuatu. Jadi yang kemudian menjadi kajian adalah proses terjadinya sebuah karya oleh pengarang yang menyangkut motif dan maksud pengarang (Hall \& Lindzey, 1985 : 5) Namun, ternyata teori ini tidak terbatas untuk menganalisis asalusul proses kreatif saja. Dalam menghadapi seorang pasien, untuk mengobati penyakitnya, seorang psikolog tidak melakukannya dengan cara menguraikan asal-usul penyakitnya, melainkan dengan cara bercakap-cakap, berdialog, sehingga terungkap seluruh depresi mentalnya, yaitu melalui pernyataan-pernyataan ketaksadaran yang tertangkap melalui bahasanya. Bahasa inilah yang kemudian dianalisis sehingga menghasilkan kesimpulan dalam terapinya. Hal ini juga dilakukan dalam analisis terhadap karya sastra. Teori Freud dimanfaatkan untuk mengungkapkan berbagai gejala psikologis di balik gejala bahasa. Oleh karena itulah, keberhasilan penelitian tergantung dari kemampuan dalam mengungkapkan kekhasan bahasa yang digunakan oleh pengarang.

Pada perkembangannya teori Freud diterima dan dikembangkan oleh para ahli berikutnya. Salah satu ahli yang mengembangkan teori psikoanalisis yang sudah digariskan Freud adalah Erik H. Erikson. Erikson (Hall \& Lindzey, 1985 : 75) lebih menekankan kepada ego dibandingkan id dan superego. Erikson melihat ego mempresentasikan "man" dalam menyatukan pengalaman dan tindakannya dalam beradaptasi. Erikson mempercayai bahwa ego bukan hanya budak (slave) dari id dan superego. 
Dalam tahap perkembangan yang diuraikan oleh Erikson dan jauh lebih rinci dibandingkan yang dicetuskan oleh Freud yaitu masa bayi (0-1 tahun) psycho-sosial krisisnya adalah tentang rasa percaya versus tidak percaya, masa kanak-kanak (1-3) psycho-sosial krisisnya tentang otonomi versus malu dan ragu, masa bermain (3-6) psycho-sosial krisisnya adalah tentang inisiatif dan rasa bersalah, masa sekolah (6-12) psychososial krisisnya adalah tentang industri dan inferioritas, masa remaja (12-20) tentang identitas dan kebingungan identitas, masa awal dewasa (20-30) psycho-sosial krisisnya tentang keintiman dan kesendirian, masa dewasa (30-65) psycho-sosial krisisnya adalah tentang menghasilkan dan stagnan, sedangkan masa tua (65+) psycho-sosial krisisnya adalah tentang kebebasan.

Berdasarkan teori Erikson
tersebut, maka perkembangan
kepribadian seseorang mengalami
berbagai macam tahapan. Pada tiap
tahapan ada bentuk-bentuk kehidupan
sosial yang menjadi tujuan sehingga
jika setiap tahap perkembangan
terlewati dengan sempurna, maka
kepribadiannya akan berkembang
dengan baik. Hal ini juga bisa dilihat
dari karya sastra, karena tokoh dalam
karya sastra merupakan cerminan
kehidupan masyarakat di luar karya.

Dalam analisis psikologi terhadap karya sastra, salah satu hal yang menjadi titik perhatian adalah tokoh, tetapi perlu disadari bahwa keseluruhan unsur disajikan melalui bahasa. Bagaimana tokoh-tokoh, gaya bahasa, latar, dan unsur-unsur lain yang muncul secara berulang-ulang, jelas menunjukkan ketaksadaran bahasa dan memiliki arti secara khas.

Analisis psikologi dalam teks sastra kemudian dikenal dengan nama psikologi sastra (Wellek dan Warren, 1976 : 81), psikologi sastra tidak bermaksud untuk memecahkan masalah psikologis praktis, tetapi secara definitif tujuan psikologi sastra adalah memahami aspek-aspek kepribadian manusia yang terkandung dalam suatu karya sastra. Meskipun demikian, bukan berarti bahwa analisis psikologi sastra sama sekali terlepas dari kebutuhan masyarakat. Karya sastra memberikan pemahaman terhadap masyarakat secara tidak langsung. Melalui pemahaman terhadap tokoh-tokohnya, masyarakat dapat memahami perubahan, kontradiksi, dan penyimpanganpenyimpang lain yang terjadi dalam masyarakat.

Berdasarkan hal di atas, maka dalam penelitian ini dilihat dengan menggunakan teori perkembangan kepribadian Erikson khususnya tentang 
psycho-social krisis yang dialami oleh tokoh Jun dalam mengahadapi persoalan yaitu perbenturan antara tradisi dan modernitas. Selain itu, akan dilihat juga peranan ego Jun dalam menghadapi persoalan tersebut.

\section{METODE PENELITIAN}

Penelitian ini merupakan penelitian kualitatif. Ini berarti analisis yang dilakukan merupakan analisis bahasa bukan angka-angka. Metode deskriptif akan dipergunakan dalam penelitian ini berisi deskripsi data penelitian. Penelitian kualitatif ini digunakan untuk mendapat data yang mendalam, suatu data memiliki makna. Makna adalah data yang sebenarnya, data yang pasti yang merupakan suatu nilai dibalik data yang tampak (Sugiyono, 2008:9).

Penelitian kualitatif mengandalkan manusia sebagai alat penelitian. Pada hakikatnya penelitian kualitatif memberikan perhatian utama pada makna dan pesan sesuai dengan tujuan dari penelitian tersebut. Hingga pada tahap akhirnya penelitian ini lebih mengutamakan proses dibandingkan dengan hasil penelitian sehingga makna bisa saja sewaktuwaktu berubah. Dalam penelitian kualitatif data yang dikumpulkan tidak berupa angka-angka sepertinya penelitian kuantitatif melainkan kata- kata yang merupakan kunci terhadap apa yang akan diteliti. Secara deskriptif laporan penelitian akan memuat kutipan-kutipan data yang memberikan gambaran yang jelas tentang objek penelitian.

Secara lebih detil lagi penelitian ini bersifat konten analisis. Hasanuddin WS (2003:40) menjelaskan bahwa konten analisis atau penelitian kajian isi kegiatannya menganalisis karya sastra dipandang sebagai produk komunikasi antara pengarang dan lingkungannya. Begitu juga dengan Bungin (2004:172) mengatakan bahwa konten analisis berhubungan dengan komunikasi dan isi komunikasi. Bahwa setiap komunikasi selalu berisi pesan dalam sinyal komunikasinya itu, berupa verbal maupun nonverbal.

Data penelitian ini adalah kalimat atau kutipan yang berhubungan dengan tokoh Jun dalam novel Tiga Cinta, Ibu karya Gus Tf Sakai. Pengambilan data dimulai dengan pembacaan dan pencatatan sesuai dengan kriteria yang sudah ditentukan. Kriteria tersebut adalah melihat tahap perkembangan kepribadian Jun yang dalam menghadapi persoalan antara tradisi dan modernitas. 
Penelitian ini menggunakan metode analisis konten yaitu metode yang bisa digunakan untuk memahami pesan dari wacana atau teks (Atmazaki, 2003:124). Oleh karena itu, dilakukan langkah sebagai berikut yaitu menginventarisasi persamaan peristiwa dalam novel, menganalisis kepribadian tokoh Jun dengan menggunakan teori Erikson tentang pschyo-social krisis yaitu dalam tahap identifikasi identitas. Selanjutnya menyimpulkan hasil penelitian.

\section{HASIL DAN PEMBAHASAN}

Pemahaman identitas melalui teori Erikson adalah dengan melihat tahap perkembangan yang dialami oleh tokoh dalam novel Tiga Cinta, Ibu karya Gus Tf Sakai. Novel ini menceritakan seorang tokoh bernama Jun yang hidup di luar daerah Minangkabau. Ia dibesarkan di Jakarta dengan segala bentuk interaksi sosialnya. Dalam masa perkembangannya ia tidak mengenal aturan-aturan adat yang digariskan oleh masyarakat sosialnya. Ia baru menyadari ia bagian dari sosial masyarakat Minangkabau adalah ketika ia akan menikahi Yani, kekasihnya yang ternyata juga gadis Minangkabau. Dalam urusan perkawinan, hal pertama yang harus dilakukan Jun adalah kembali ke kampung halaman untuk meminta restu. Di sanalah permasalahan terjadi, setelah diselidiki secara silsilah adat Yani masih satu garis keturunan dengan Jun, artinya jika mereka menikah, pernikahan mereka adalah pernikahan sesuku. Perhatikan kutipan berikut.

$\begin{array}{lr}\text { Siapakah } & \text { Khadijah? } \\ \text { Ternyata } & \text { ia } \\ \text { adalah....ibunya } & \text { Yani! } \\ \text { Dan dalam } & \text { masyarakat } \\ \text { matrilineal, } & \text { mereka } \\ \text { adalah sesuku. Dan cerita } \\ \text { tentang } \\ \text { sesuku...adalah pernikahan }\end{array}$

(Sakai, 2003 ; 11)

Kutipan di atas memperlihatkan bahwa persoalan pernikahan seseku yang dipandang tabu dalam adat matrilineal. Jun yang berada di luar tradisi merasa tidak terima dengan kekangan tradisi yang tidak memperbolehkan menikah sesuku yang diatur dalam adat pernikahan di Minangkabau. Syaratsyarat pernikahan menurut adat Minangkabau, Fiony Sukmasari menjelaskan dalam Amir (2006:1213) ada tiga syarat, yaitu : 1) kedua calon mempelai harus beragama Islam, 2) kedua calon mempelai tidak sedarah atau tidak berasal dari suku yang sama, kecuali pesukuan itu berasal dari nagari atau luhak yang lain, 3) Kedua calon mempelai dapat saling menghormati dan menghargai 
orang tua dan keluarga kedua belah pihak, dan 4) Calon suami (marapulai) harus sudah mempunyai penghasilan untuk dapat menjamin kehidupan keluarganya.

Perkawinan yang dilakukan tanpa memenuhi semua syarat di atas dapat dianggap perkawinan sumbang, atau perkawinan yang tidak memenuhi syarat menurut adat Minangkabau. Selain dari itu, masih ada tata krama dan upacara adat dan ketentuan agama Islam yang harus dipenuhi seperti tata krama japuik manjapuik, pinangmeminang, batuka-tando, akad-nikah, baralek gadang, jalang menjalang, dan sebagainya.

Permasalahan yang dihadapi Jun tidak hanya soal perkawinannya dengan Yani yang tidak direstui, tetapi lebih kepada persoalan Jun yang tidak lagi mau terikat dengan kekangan adat tersebut. Pada tahap inilah Jun mengalami konflik yang berkaitan dengan egonya. Seperti yang dikemukakan oleh Erikson (Hall dan Lindzey, 1985 : 75) bahwa ego adalah bukan semata dorongan dalam diri, tetapi juga dipengaruhi oleh lingkungan dan kebudayaan. Ini adalah sumbangan terbesar Erikson dalam teori perkembangan kepribadian. Hal ini dapat dijelaskan bahwa Erikson percaya bahwa ego juga dipengaruhi oleh lingkungan sosial serta budaya masyarakat.
Dalam memahami hal tersebut, bisa dilihat pada tokoh Jun sebagai representasi laki-laki Minangkabau yang sudah tidak lagi terikat pada tradisi, namun sepenuhnya ia tidak bisa lepas dari tradisi tersebut. Lihat kutipan berikut.

Sebagai seorang yang beradat,
sebagai anak mak dan sebagai
keturunan, segala tatanan akan
turun temurun. Begitu kau
lahir, maka kau telah berada
dalam seperangkat tata cara
yang memberi kau status. Bagi
Mamak Odang-mu-penghulu
suku kita, status adalah tanda
bagi keberadan; lebih penting
dari apapun...." (Sakai, 2003;
10)

Kutipan di atas memperlihatkan bahwa tokoh Jun yang merasa dirinya bukan bagian dari tradisi Minangkabau merasa terasadarkan pernyataan orang tuanya /Begitu kau lahir, maka kau telah berada dalam seperangkat tata cara yang memberi kau status/ yang menyiratkan bahwa sebagai seseorang begitu dilahirkan ia menerima seperangkat status sosial. Dalam hal ini Jun yang dilahirkan dalam adat Minangkabau merupakan bagian dari suatu suku, kemenakan dari mamaknya, anak pisang dari keluarga suku ayahnya dan seperangkat status adat lainnya. Sehingga, persoalan status sosial akan 
menjadi pertimbangan bersama, tidak menjadi persoalan pribadi sang anak.

Hal inilah yang dialami oleh Jun yang terlahir dari seorang perempuan Minangkabau. Begitu ia lahir, ia diakui menjadi bagian sosiokultural Minangkabau walaupun ia tidak dilahirkan di daerah Minangkbau, tidak mengenal budaya tersebut dengan baik dan tidak mempraktekkan dalam kehidupan sehari-hari. Jun telah tumbuh besar di Rantau yaitu Jakarta. Hidup dalam tatanan norma yang berbeda membuat pikiran Jun tidak lagi merasa dekat dengan adat tradisi. Perhatikan kutipan berikut.

\begin{abstract}
"Aku dilahirkan di sini, Wan Datuk, tapi saat itu aku belum bisa menyerap apa-apa. Aku dibesarkan di tempat lain, Wan Datuk, dan di tempat lain itulah aku mengenal diri”
\end{abstract} (Sakai, 2003 ; 14)

Pada kutipan tersebut terlihat upaya Jun menjelaskan bahwa dia sepenuhnya tidak bisa disalahkan atas pilihannya untuk menentang adat istiadat yang mengekangnya. Ia sepenuhnya ingin dipandang sebagai orang luar, yang bukan lagi bagian dari adat istiadat tersebut. /Aku dibesarkan di tempat lain, Wan Datuk, dan di tempat lain itulah aku mengenal diri/ kalimat tersebut memperlihat tahap perkembangan yang dilalui oleh tokoh Jun, bahwa tahap ia mengenal diri dan lingkungannya tidaklah di Minangkabau. Jika menurut pendapat Erikson, Jun mengalami masa kanakkanak sampai dewasa di Jakarta. Artinya dalam perjalanan mencari identitas, ia tidak mengenal tata cara atau norma-norma yang berhubungan dengan adat istiadat Minangkabau. Ia lebih mengenal tempat ia dibesarkan dibandingkan tempat ia dilahirkan sesuai dengan kalimat /Aku dilahirkan di sini, Wan Datuk, tapi saat itu aku belum bisa menyerap apa-apa/ pernyataan bahwa ia tidak menyerap apa-apa di tanah kelahirannya mengindikasikan bahwa ia tidak mengenal sosio kultural tempat ia dilahirkan dengan baik.

Perbedaan pemahaman antara Jun dan keluarganya di kampung tidak menemui titik temu. Jun masih berkeras ingin menikahi Yani karena menurutnya menikah adalah pilihan perorangan tidak persoalan sosial atau masyarakat. Perhatikan kutipan berikut.

\footnotetext{
“...Tapi untuk berada dalam perkawinan, apakah bukannya yang lebih penting adalah kecocokan antara masing-masing pribadi?...makanya ia tidak pernah berpikir tentang asalusul, atau semacam tetek
} 
bengek latar belakang, tetapi

kini?" (Sakai, 2003 ; 5)

Pada kutipan di atas terlihat kebingung tokoh Jun dalam memahami perkawinannya yang menjadi polemik bagi keluarganya di kampung. Jun beranggapan bahwa perkawinan adalah soal kecocokan pribadi dua orang yang akan menikah, bukan soal hal lainnya. Ini sesuai dengan skema perkembangan kepribadian Erikson pada tahap awal dewasa, Jun sedang berada pada bahwa cinta adalah soal kedekatan dua manusia yang sama-sama mempunyai keinginan untuk saling mencintai. Pada tahap ini identitas sosial-kultiral harus terbentuk dan dipahami dengan baik, jika tidak akan sama seperti Jun yang mengalami kegamangan ketika ia merasa sudah siap untuk menikahi Yani, ada hal-hal di luar yang dipahaminya yang harus ia ikuti. Dan ini menyebabkan Jun menjadi berada dalam dilemma antara kehidupan modern yang mengajarkannya untuk mementingkan dirinya sendiri atau tradisi yang sangat dijunjung erat di tanah kelahirannya.

Jika dilihat dalam susunan struktur kepribadian, id tokoh Jun mengingkan bahwass ia harus tetap menikahi Yani dan ia tidak ingin mempermasalahkan hal lain di luar keinginannya. Sedangkan Ego dalam hal ini bertindak sebagai penghubung dengan realita. Jun mempertanyakan keputusan Mak dan Wan Datuk yang melarangnya menikahi Yani karena pernikahan yang sesuku. Dalam hal ini superego Jun yang justru tidak dibesarkan dalam norma-norma yang sama dengan Mak dan Wan Datuk tidak terlalu berperan. Sehingga Jun lebih mementingkan pada tindakan yang akan dilakukannya (Ego). Merujuk pendapat Erikson bahwa Ego tidak semata-mata budak dari Id an Superego, tetapi juga dipengaruhi oleh sosial kultural terlihat dalam kasus yang di alami oleh Jun. Jun mengikuti egonya bukan semata-mata karena doronngan id, tetapi karena sosio kultural yang menjadi bagian dalam tahap perkembangannya.

Jun yang hidup dan mengalami tahap perkembangan kepribadian dengan norma-norma yang berbeda sekali dengan norma-norma Mak dan Wan Datuk memiliki pandangan yang berbeda tentang permasalahan pernikahan Jun. Lihat kutipan berikut.

\footnotetext{
"Be-begini. Justru... karena tak ingin melihatnya secara terpisah aku ke sini. Justru.. karena ingin mempertemukan jaraklah aku kemari. Dan lazimnya interaksi antara dua titik, bukankah konsekwensinya adalah perubahan? Pergeseran?" (Sakai, 2003 ; 24)
} 
Pada kutipan di atas, terlihat usaha Jun dalam memahami sosial kultural yang dipercayai oleh Mak dan Wan Datuk. Jun bersikap tidak egosentris, ia berusaha mencari titik temu dari permasalahan tersebut. Hal ini memperlihatkan bahwa Jun berada pada tahan psycho krisis tentang kebingungan akan identitasnya. Jun ingin menemukan dua titik perbedaan yang menghambat pernikahannya dengan Yani. Ia menyatakan bahwa ia memang mengakui sebagai bagian dari budaya yang melahirkannya /Be-begini. Justru... karena tak ingin melihatnya secara terpisah aku ke sini. Justru.. karena ingin mempertemukan jaraklah aku kemari/ Jun berada dalam kebimbangan antara identitasnya sebagai orang yang tidak terikat tradisi dengan identitas sebagai masyarakat tradisi. Jun ingin memberi pemahaman bahwa ketika dua titik permasalahan bertemu, bukannya seharusnya terjadi pergeseran atau perubahan. Pertanyaan besar yang membuat Jun semakin berada dalam dilema karena pada kenyataannya ia melihat tidak ada titik temu dalam tradisi dan modernitas yang mengikatnya. Ia adalah bagian modernitas yang mengukuhkan bahwa ia tidak ingin dikekang tradisi, tapi tradisi berdiri kuat bahwa ia yang terlahir bagian darinya tidak bisa begitu saja mengabaikan keberadaannya. Hal inilah yang dirasakan Jun menjadi perdebatan yang tidak usai dalam usahanya mencari jati diri.

Perhatikan kutipan berikut.

"Pergeseran atau apapun

namanya! Tak akan -kataku!"

"Mamak.."

Tangan sang mamak

mengempas meja.

Bergedubrak. "berubahlah

sendiri Bergeser...,"

gerahamnya gemeretak.

"bergerserlah sendiri." (Sakai,

$2003 ; 24)$

Pada kutipan tersebut terlihat bahwa Jun yang sedang mengalami kebingungan terhadap identitas sosial kulturalnya dihadapkan dengan kenyataan bahwa tradisi adalah sesuatu yang tidak bisa ia tawarkan perubahan. Sebagai bagian dari masyarakat tersebut Jun harus mengikuti semua tatanan yang ada. Mamak sebagai representasi tradisi menolak penawaran Jun untuk perubahan. Ego Jun untuk bernegosiasi dengan Mamak adalah sebuah upaya pemenuhan keinginannya untuk mendapatkan apa yang dia inginkan. Sedangkan Mamak sebagai representasi superego menolak segala bentuk keinginan Jun yang sangat bertentangan dengan adat istiadat yang berlaku. /bergeserlah sendiri/ adalah pernyataan bahwa adat istiadat sebagai representasi superego 
adalah tatatan yang kuat dan tidak bisa dirubah oleh berbagai keadaan.

Perhatikan kutipan berikut ini.

"Jun terbelalak. Jadi.. memang beginilah ia. Inilah lembah itu. Lembah yang benar-benar lembah. Dan kabut yang benar-benar kabut?

Dan Jun terhempas

Remuk

Memang tidak ada perubahan di sini. Sama sekali tak! Dan tiba-tiba, dalam

keterhempasannya., sesuatu berkelebat dan seperti menyesak:"....tapi Nak, jika kita mampu menyesuaikan diri dengan masa dan kondisi, kesenangan memang akan terdapat di mana-mana."

(Sakai, 2003 ; 24)

Pada kutipan tersebut, pada akhirnya Jun memahami bahwa sebagai bagian dari tradisi, Jun tidak bisa menerapkan pemikirannya yang modern. /memang tidak ada perubahan di sini/ adalah bentuk pemahaman Jun tentang persoalan yang dihadapinya. Jun memahami bahwa keinginannya (id) untuk menikahi Yani yang sesuku dengannya tidak akan pernah bisa diterima di dalam tatanan adat yang dikenalnya di sini. Segala sesuatu yang berada di sini adalah dalam formula-formula yang sudah pasti dan tidak bisa di ubah-ubah. Tindakan (ego) Jun tidak bisa diterapkan dalam masyarakat adat, ia terpaksa mengalah pada superego yaitu tatanan adat yang mengikatnya.

Pada akhirnya Jun memahami bahwa pemahamannya tentang sosio kultural tanah kelahirannya adalah sesuatu yang tidak akan memenuhi keinginannya untuk menikahi Yani. Salah satu cara untuk pemenuhan itu adalah dengan tidak mengikuti aturan itu sama sekali. Perhatikan kutipan berikut.

"Jika ternyata tatanan itu tidak berubah dan kalian tetap menikah, maka, bagi sanak famili kita di Lembah, kau bisa saja di buang sepanjang adat..."( Sakai, 2003 ; 26)

Pada kutipan tersebut, Jun pada akhirnya dihadapkan pada kenyataan untuk memilih identitasnya, sebagai bagian dari masyarakat adat atau terlepas dari kekangan tersebut dan menjadi masyarakat modern. Walaupun dalam hal ini terlihat konsekwensi yang harus diterima Jun sebagai bagian dari masyarakat adat. /kau bisa saja di buang sepanjang adat/ adalah pernyataan yang mengindikasikan bahwa seseorang tidak lagi diakui secara adat. Artinya, jika Jun tetap menikahi Yani, maka ia terbuang dari sanak keluarganya, ia 
bukan lagi bagian dari masyarakat adat.

\section{Pada tahap inilah Jun berada pada proses pembentukan kepribadian. Ia dihadapkan pada pilihan yang tidak mudah. bahwa ia ternyata juga bagian dari masyarakat. Hidupnya tidak seutuhnya milik dia pribadi tapi juga milik masyarakat tempat ia dilahirkan.}

Konflik yang dihadapi Jun mengharuskannya memilih di antara dua pilihan yang tidak mudah. Pada akhirnya ia memutuskan untuk tetap pada tujuan awalnya menikahi Yani dan meninggalkan identitasnya sebagai bagian dari masyarakat adat. Perhatikan kutipan berikut.

Ah, apa boleh buat. Asal...tidak dibuang oleh Mak.

Dan Tuhan. (Sakai, 2003 ; 26)

Pada kutipan tersebut dapat dilihat bahwa pada akhirnya Jun menentukan identitasnya sebagai masyarakat modern dengan meninggalkan identitas sebagai bagian dari masyarakat adat. Pada kutipan /Asal...tidak dibuang oleh Mak. Dan Tuhan/ adalah bentuk keputusan akhir yang diambil Jun.

Jun yang hidup dan berkembang dalam masyarakat modern memahami segala sesuatu dalam perspektif keindividualisasian. Seperti salah satu ciri masyarakat modern yaitu hubungan antar manusia terutama didasarkan atas kepentingankepentingan pribadi. Hal ini sangat bertentangan dengan masyarakat tradisi. Sehingga ketika Jun berada di dua keadaan, ia tidak sepenuhnya mampu menerima kenyataan bahwa kehidupan pribadinya harus ditentukan oleh sistem adat. Bagi Jun yang modern, hubungan manusia dengan manusia hanyalah terbatas pada tujuan pribadi tertentu.

Kebingungan identitas Jun yang dalam Erikson di alami oleh pada tahap perkembangan remaja. Jun berada mengalami tahap-tahap perkembangan dalam kehidupan modernisasi yang telah menjadi bagian dari kebudayaannya. Menurut Delanty ada tiga manifestasi modernitas sebagai proses kultural: pengetahuan, kekuasaan dan identitas diri. Pengetahuan sebagai manifestasi modernitas memiliki tiga sifat, otonom, emansipatoris dan universal. Pertama, pengetahuan dihasilkan oleh kaum intelektual sekular dan bukan lagi oleh elite religius yang memonopoli kebenaran. Produksi pengetahuan juga semakin otonom dari negara, gereja dan institusi sosial lainnya. Produksi pengetahuan menjadi lebih profesional, terspesialisasi dan terlembaga dalam lembaga-lembaga yang otonom, seperti lingkungan akademis dan universitas. Pengetahuan yang 


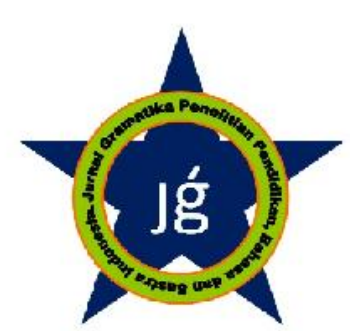

demikian menjadi penting bagi nasionalisme, karena nasionalisme dikonstruksikan atas dasar pengetahuan historis dan geografis. Kedua, pengetahuan bersifat emansipatoris. Dalam modernitas, khususnya pada Abad Pencerahan, pengetahuan adalah kekuasaan. Pengetahuan dapat menantang tatanan sosial dan politik yang berlaku. Aspek ini menjadi penting bagi formasi negara dan negara-bangsa Ketiga, pengetahuan dalam modernitas ditandai oleh universalitas. Universalitas di sini berarti bahwa klaim kebenaran pengetahuan dapat diterima oleh semua, tetapi juga dapat diperdebatkan oleh semua. Maka secara paradoksal, modernitas juga mendorong kepada tumbuhnya relativisme. Dalam modernitas terjadi dua kecenderungan ekstrem, yaitu universalisme mutlak dan partikularisme(Sastrapratedja, 2013).

Dari skema tersebut, terlihat penolakan Jun terhadap superego yang direpresetasikan dalam bentuk adat istiadat Minangkabau. Jun sepenuhnya mempercayai tindakan atau egonya karena ia dibesarkan dalam kehidupan modernitas yang mempunyai tata aturan tertentu yang berbeda jauh dengan tradisi.

Berdasarkan analisis data di atas, maka secara keseluruhan dapat dilihat kepribadian tokoh Jun dalam menghadapi permasalahan dalam perkawinannya yang ditentang oleh adat istiadat tempat ia dilahirkan. Secara sederhana, perhatikan skema tentang kepribadian Jun dalam menghadapi masalah perbentunran antara tradisi dan modernitas yang dialaminya, sebagai berikut : 


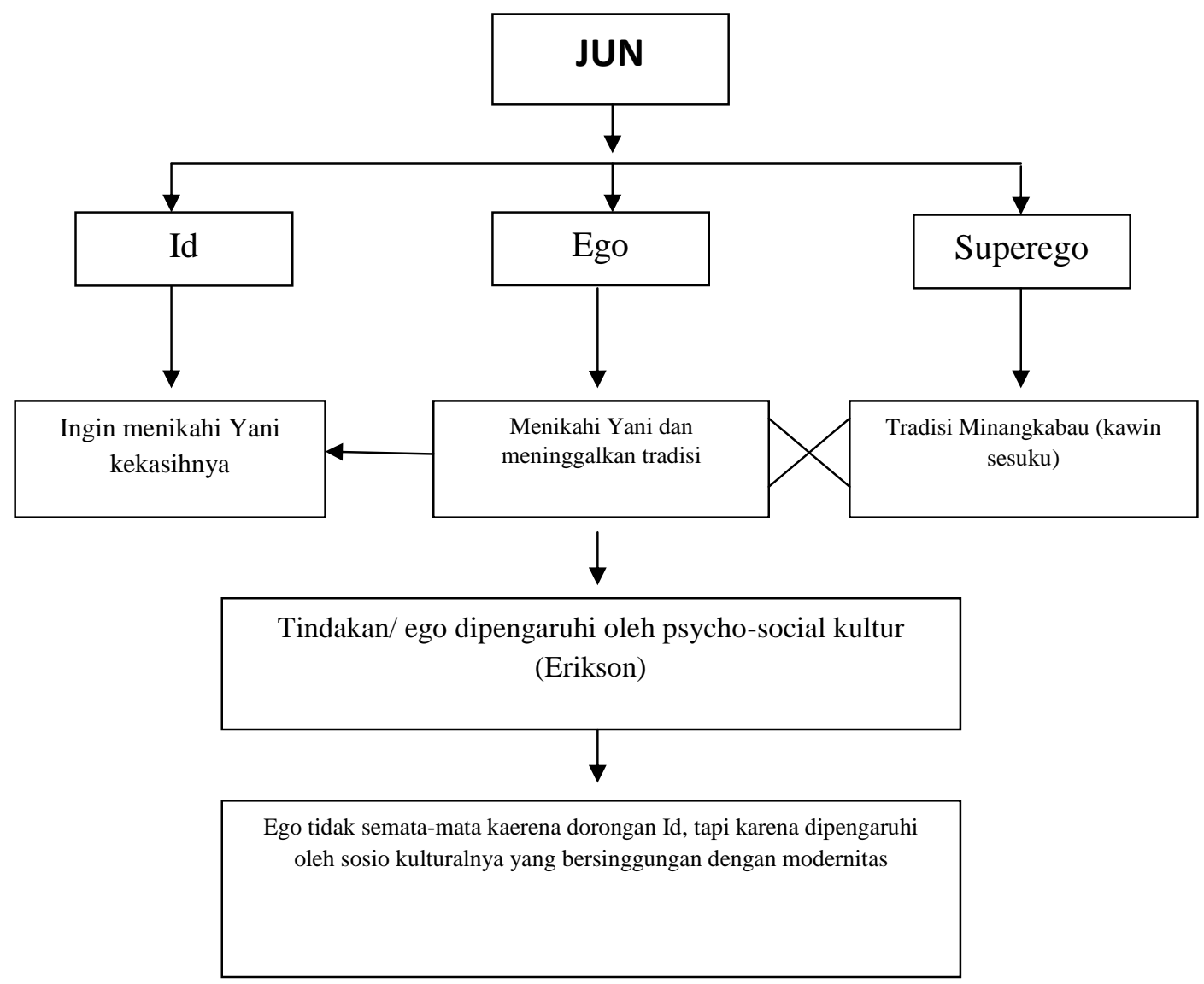

SIMPULAN

Permasalahaan identitas yang terepresentasi melalui tokoh Jun dalam novel Tiga Cinta, Ibu karya Gus Tf Sakai memperlihatkan kegamangan masyarakat modern dalam menghadapi kekangan adat. Tokoh Jun merupakan representasi masyarakat Minangkabau yang mengalami kegamangan terhadap identitas sosialnya dikarenakan terjadinya benturan antara tradisi dan modernitas.

Hasil penelitian menunjukkan bahwa novel Tiga Cinta, Ibu karya Gus
Tf Sakai memperlihatkan permasalahan identitas berupa kebingungan identitas (identity confusion) yang dialami tokoh Jun sebagai orang Minangkabau yang telah lama hidup di luar Minangkabau. Identitasnya sebagai orang Minangkabau membuatnya harus berada dalam ikatan tradisi tersebut yang memaksanya untuk tidak menikahi calon istrinya karena silsilah adat. Kebingungan ini membuat tokoh Jun berada dalam dilema untuk menerima atau menolak dalam 
perbenturan tradisi dan modernitas yang dialaminya. Pada akhirnya ia memutuskan tidak mengikuti aturan tradisi. Pilihan yang diambil oleh tokoh Jun adalah bentuk krisis identitas yang dialami oleh sebagaian masyarakat dewasa ini.

\section{UCAPAN TERIMA KASIH}

Terima kasih kepada pihakpihak yang telah membantu peneliti dalam menyelesaikan penelitian ini. Adapun beberapa pihak yang telah mendukung peneliti baik secara moril dan material yaitu pertama, pihak institusi yang telah memberikan kesempatan pada peneliti untuk terus berkarya dengan membantu secara moril dan material. Kepada kedua orang tua dan keluarga yang senantiasa memberikan motivasi sehingga peneliti bisa menyelesaikan penelitian ini tepat waktu dan pada pihak-pihak yang tidak mungkin disebutkan satu persatu. Semoga penelitian ini bisa menambah wawasan dan bermamfaat buat perkembangan ilmu pengetahuan.

\section{DAFTAR PUSTAKA}

Bordiue, Pierre. 2007. Langguage \& Symbolic Power. USA ; Polity Press.

Budianta, Melani dkk. 2008. Membaca Sastra. Magelang : Indoensia Tera.
Bungin, Burhan. 2004. Metodologi Penelitian Kualitatif Aktualisasi Metodologis ke Arah Ragam Varian Kontemporer. Jakarta: Rajawali Pers

Freud.1997. The Interpretation of Dream. London : Worldsworth Classics of World Literature.

Hall, S Calvin dan Gardner Lindzey. 1985. Introduction to Theories of Personality. Canada : John Wiley \& Sons, Inc.

Hastuti, N. (2014). Dampak permasalahan hidup empat tokoh utama terhadap kepribadian dalam novel auto karya natsuo kirino. Ejournal.undip.ac.id, III(NO I), 19-33.

Hermayulis. 2011. Peranan dan Kedudukan Perempuan Melayu dalam Masyarakat Matrilineal Minangkabau di Sumatera Barat . Jakarta : Universitas Yarsi

Jenkins, Richard. 2010. Membaca Pikiran Pierre Bourdieu. Bantul : Kreasi Wacana.

Letche, John. 2001. 50 Filsuf Konte mporer (terj : A. Gunawan Admiranto dari buku Fifty Key Contemporary Thinkers). Yogyakarta : Kanisius

Sakai, Gus Tf. 2003. Tiga Cinta Ibu. Jakarta : PT Gramedia Pustaka Utama

Sastrapratedja, M. (2013). Nasionalisme Dan Modernitas, 295. 